\title{
Zagotavljanje višje kakovosti razvijanja pismenosti $z$ vidika vertikalnega povezovanja predopismenjevalnih spretnosti med Kurikulumom za vrtce in Učnim načrtom za slovenščino
} Katarina Grom

\section{Uvod}

Paradigma predšolske vzgoje doživlja preporod - če je bila funkcija predšolske vzgoje v 70-tih letih usmerjena v varstvo in vzgojo otrok, je v sodobnem času bistveno bolj usmerjena tudi v pridobivanje novih znanj (Hachey, 2013). Diskurz pedagogike zgodnjega otroštva je povezan z novimi spoznanji nevroznanosti, ki preučuje razvoj in delovanje možganov (Farquhar in White, 2014). Sodobna paradigma sprememb v povezavi s kurikularnimi izhodišči Hachey (2013) se nanaša: (i) na izkušnje otrok, ki so bile pred desetletji drugačne kot danes, (ii) na vedenje o otrokovem razvoju in načinu učenja ter (iii) na pričakovanja (Lucariello et al., 2015; Nacionalna strategija za razvoj bralne pismenosti za obdobje 2019-2030, 2019), ki so povezana z védenjem predšolskega otroka. Spremembam vzgojno-izobraževalnega delovanja sledijo tudi kurikularni programi, ki so v sedanjem času zaradi gospodarsko-ekonomskih koristi vedno bolj podvrženi ocenjevanju kakovosti glede na njihovo učinkovitost (Bole et al., 2016; Heckman, 2012). Zahtevnost znanja, v kontekstu družbenega delovanja svetovne globalizacije s hitrimi spremembami, predstavlja na vseh ravneh posameznikovega vzgojno-izobraževalnega obdobja nov družbeni izziv (Vallberg-Roth, 2014). V Sloveniji smo se v preteklem času prilagajali družbenim spremembam ter jih upoštevali tako, da so kurikularni snovalci vzgojno-izobraževalnega sistema v času povečanih potreb po predšolski oskrbi v drugi polovici 20. 
stoletja oblikovali Vzgojni program za vzgojo in varstvo predšolskih otrok (1979). Program je bil v začetku osemdesetih let dopolnjen z Vzgojnim programom priprave otrok na osnovno šolo (1981), kjer je bila poudarjena izobraževalna komponenta, ki je služila pripravi otrok na formalno izobraževanje v osnovni šoli. Korenite spremembe so v kurikularnih dokumentih za predšolsko vzgojo nastale konec 9o-tih let - kot zadnji nacionalni dokument za predšolsko vzgojo pa poznamo pod imenom Kurikulum za vrtce (1999). Temeljna sprememba novo zasnovanega programa upošteva predhodni kurikularni deficit učno-snovnega načrtovanja, zato je bil le-ta preoblikovan v učno-ciljno načrtovanje, ob čemer se navezuje na procesno-razvojno naravnanost posameznika. Najnovejši kurikulum v primerjavi s prejšnjima nacionalnima dokumentoma opredeljuje cilje, iz katerih izhajajo načela za njihovo uresničevanje. Strokovni delavci morajo tako cilje kot načela povezovati $\mathrm{v}$ operativne načrte in nato vzgojne dejavnosti prilagajati starostni skupini otrok (Kroflič, 2001: 16). Vrtčevski kurikulum (Kurikulum za vrtce, 1999) temeljno opredeljuje šest področij posameznih dejavnosti: gibanje, umetnost, družbo, naravo, matematiko in jezik - slednji je predmet analize raziskave $\mathrm{z}$ vidika razvijanja predopismenjevalnih spretnosti. Le-te so v kurikularni zasnovi opredeljene pri jeziku (Kurikulum za vrtce, 1999: 20), nekatere segmente, ki so vezani na predopismenjevanje, pa prepoznamo tudi na drugih področjih programa, npr. pri gibanju, umetnosti ali na glasbenem področju.

Predbralne, predpisalne in predračunske učne spretnosti pridobivajo v predšolskem obdobju vedno večji pomen (Richman in Rescorla, 2015), sem pa v sklopu kurikuluma na področju jezika sodijo tudi predopismenjevalne spretnosti (Kurikulum za vrtce, 1999: 20). Kurikulum (ibid) ciljno na področju jezika navaja »razvijanje predbralnih in predpisalnih spretnosti«, v svojih načelih pa izpostavlja "vertikalno povezovanje med vrtcem in šolo« (ibid: 8). V nadaljevanju izpostavi, da predšolsko obdobje ni namenjeno "pripravi otrok na naslednjo stopnjo vzgoje in izobraževanja« (ibid: 10), kar lahko razumemo kot odmev na prejšnjo zasnovo predšolskega programa (Vzgojni programom priprave otrok na osnovno šolo, 1981), ko je bila najpomembnejša naloga zadnjega leta predšolskega delovanja priprava otroka na šolo. Prav nasprotno kot Kurikulum za vrtce (1999) pa evropski komisar za izobraževanje, kulturo in mladino Figel (Turnšek in Zorec Batistič 2009: 3) izpostavlja pomen predšolske vzgoje kot temelj za poznejše izobraževanje, ter meni, da predšolska vzgoja v sodobnem času predstavlja neposreden izziv vsakega izobraževalnega sistema. Tako Jalongo (2015) 
podpira idejo o intenzivnejšem pridobivanju učnih spretnosti v predšolskem obdobju, še posebno na predbralnem, predpisalnem in predmatematičnem področju, saj so tako otroci bolje pripravljeni na naslednjo stopnjo izobraževanja. Soydan (2015) Jalongovo idejo dopolni s poudarkom, da morajo biti te spretnosti vključene $\mathrm{v}$ predšolski program, a opozori na upoštevanje otrokovega razvoja. Študija Požar Matijašič et al. (2017) razpravlja o prehajanju otrok iz vrtca $\mathrm{v}$ osnovno šolo ter podrobno predstavi omejitve, ki se navezujejo na vez med obema vzgojno-izobraževalnima inštitucijama. Avtorice med drugim opozarjajo na šibko sodelovanje med deležniki, tj. vrtcem in osnovno šolo, ter neenako jezikovno podporo otrokom. Avtorice menijo, da lahko na razvojnih področjih pozitivni učinki izzvenijo, če ni zagotovljena strokovna kontinuiteta in povezanost med obema vzgojno-izobraževalnima sistemoma.

\section{Opredelitev raziskovalnega problema}

Ob pregledu slovenske literature ni mogoče zaslediti raziskav, ki bi na področju jezika $\mathrm{z}$ vidika povezovanja predopismenjevalnih spretnosti podrobno preučevale kurikularna dokumenta, tj. Kurikulum za vrtce (1999), ki se navezuje na predšolsko vzgojo, in Učni načrt za slovenščino (2011), vezan na prvo vzgojno izobraževalno obdobje.

Raziskovalci, ki se ukvarjajo s predšolsko vzgojo in začetnim šolskim izobraževanjem (Cunningham, 2010; Lane et al., 2014; Marjanovič Umek et al., 2019; Pečjak in Potočnik, 2011; Ropič, 2016, Skubic, 2012, 2013), opozarjajo na vrzeli, ki so povezane z zgodnjo in začetno pismenostjo. Skubic (2012) ugotavlja, da bi morali strokovni delavci predšolske vzgoje izpopolniti védenje na jezikovnem področju, še posebej na področju zgodnje pismenosti, opozarja pa tudi na jasnejšo opredelitev dejavnosti za predopismenjevanje (ibid) v Kurikulumu za vrtce (1999). Dodatno na področju jezika, ki vsebuje otrokovo poznavanje tiska, Skubic (2013) predlaga, da bi strokovni delavci temu področju lahko namenili več spodbud. $Z$ vzdolžno študijo so Marjanovič Umek et al. (2019) preučevale učinke trimesečnega dodatnega programa v vrtcu, ki je spodbujal zgodnjo pismenost otrok. Pri tem so ugotovile pomemben napredek na področjih metajezikovnega zavedanja, pripovedovanju zgodb in grafomotoričnih spretnostih. Pečjak in Potočnik (2011) sta predstavili rezultate, iz katerih je razvidno, da ima le tretjina otrok ob vstopu v osnovno šolo ustrezno razvite spretnosti, ki so potrebne za začetno opismenjevanje. Prav tako Ropič (2016) opozarja na opuščanje predopismenjevalnih aktivnosti pri otrocih prvega razreda osnovne šole, 
čeprav so morali strokovni delavci, ki so bili vključeni v uvajanje 9-letne osnovne šole opraviti dodatno izobraževanje (Odredba o postopnem uvajanju programa 9-letne osnovne šole, 1998: 16. člen) - tudi s področja jezika, kar naj bi omogočilo uspešnejši prehod otrok iz vrtca v osnovno šolo (Cencič in Horvat, 2021: 49).

Oba nacionalna dokumenta dopuščata strokovnim delavcem, da na podlagi kurikularnih smernic in avtonomnega strokovnega znanja izberejo ožja področja, ki so povezana s predopismenjevalnimi spretnostmi ter sami določajo čas in intenziteto predopismenjevalnih aktivnosti. Čeprav je Kurikulum za vrtce (1999) zasnovan na spoznanjih stroke in pomeni za strokovne delavce podlago za avtonomno delovanje na področju jezika, Učni načrt za slovenščino (2011) pa v razdelku razvijanja zmožnosti branja in pisanja opredeli razvijanje predopismenjevalnih spretnosti, ostaja nepojasnjeno vprašanje, ali konceptualna zasnova kurikuluma in učnega načrta kaže ustrezne povezave s posameznimi področji za razvijanje predopismenjevalnih spretnosti.

\section{Cilj raziskave}

$\mathrm{V}$ raziskavi nas je zanimalo, kako se nacionalna dokumenta, tj. Kurikulumoma za vrtce (1999) na področju jezika in Učnega načrta za slovenščino (2011) v prvem vzgojno-izobraževalnem obdobju na podlagi posameznih področij za razvijanje predopismenjevalnih spretnosti povezujeta s cilji, načeli, metodami in priporočili za strokovne delavce.

\section{Metodološka opredelitev raziskave}

$\mathrm{V}$ raziskavi je bil uporabljen kvalitativni empirični pristop (Kordeš in Smrdu, 2015; Sagadin, 2007) z vključevanjem primerjave dveh različnih nacionalnih dokumentov, ki se uporabljata v predšolskem obdobju (Kurikulum za vrtce, 1999) in začetnem šolskem obdobju za slovenščino (Učni načrt za slovenščino, 2011) ${ }^{1}$. Uporabljena je bila deskriptivna metoda analize vsebine; pri Kurikulumu za vrtce (1999) je analiza vključevala področje jezika, pri Učnem načrtu za slovenščino (2011) pa je bilo analizirano prvo vzgojno-izobraževalno obdobje, področje razvijanje zmožnosti branja in pisanja. Glede na relevantno strokovno literaturo (Baloh, 2019; Cunningham, 2010; Dickinson et al., 2019; Hair et al., 2006; Lane et al., 2014; Marjanovič 
Umek et al., 2019; Mata, 2011; Önder et al., 2019; Pečjak, 2012; Ropič et al., 2003, 2016; Saksida, 2017; Skubic, 2012, 2013; Teale, 2018; Wawire et al., 2018) smo identificirali osem ključnih področij za spodbujanje razvijanja predopismenjevalnih spretnosti: interes za branje, koncept tiska, besedišče, vidno zaznavanje, fonološko zavedanje, abecedno znanje, orientacija in grafomotorika.

Takšen način zbiranja podatkov dopušča nevsiljivo in nereaktivno metodo, saj je bilo analizirano empirično gradivo neodvisno od raziskovalnega procesa. Analiza je temeljila na "nemih« dokumentih, ki že obstajajo (Vogrinc, 2008) in tako niti en niti drug dokument nista nastala za potrebe te raziskave, temveč sta bila oblikovana v okviru kurikularne prenove za vrtec in osnovno šolo (ibid).

\section{Vrste dokumentov}

Izbrana preučevana dokumenta se uvrščata med uradne nacionalne dokumente in predstavljata okvir za kakovostno načrtovanje, izvedbo in evalvacijo pedagoškega dela. V njiju so zapisani (splošni/operativni) cilji, načela uresničevanja ciljev, področja dejavnosti ( $\mathrm{v} v \mathrm{rtcu}$ ), vsebine, skladne s starostnim obdobjem otroka, didaktična priporočila in standardi znanja.

\section{Prednosti in pomanjkljivosti analize dokumentov}

Prednosti analize dokumentov so bile $\mathrm{v}$ raziskavi prepoznane $\mathrm{v}$ tem, da ni bilo časovne in prostorske omejitve, empirično gradivo je bilo ves čas na voljo, analiza dokumentov je omogočala preučevanje zapisanih besedil, dostopnost dokumentov pa je bila zagotovljena na spletnih straneh (Vogrinc, 2008: 125).

\section{Identifikacija osmih temeljnih kategorij in pripis pojmov}

$\mathrm{Na}$ osnovi relevantne strokovne literature je bilo oblikovanih osem kategorij s predpostavko performativne vrednosti (Kogut in Ragin, 2006: 45). Z beleženjem pojava (ali nepojava) kategorije ali pojma v izbranem dokumentu je bila dosežena transparentnost, katere kategorije in/ali pojmi so pogosto ali manj pogosto izpostavljeni $\mathrm{v}$ dokumentu, kar pomeni intenzivnost oziroma pogostost kategorije.

Interes za branje - Pri izbiri bralnih gradiv upoštevamo otrokov interes, a je pomembno, da s strokovno spodbudo posežemo tudi po zahtev- 
nejših besedilih. Bralni dogodek (Saksida, 2009) vodi strokovni delavec kot bralni model.

Koncept tiska - Koncept tiska opredelimo v petih kategorijah: orientacija knjige, razlikovanje med slikami in besedilom, smer tiska, poznavanje začetka/konca zgodbe v knjigi ter začetek/konec besedila in uporaba knjižne terminologije.

Besedišče - Razvijanje besedišča je povezano s količinskim in kakovostnim vidikom. Količinski vidik pa se nanaša na fluentnost in fleksibilnost besedišča.

Vidno zaznavanje - Vidno zaznavanje obsega štiri dimenzije: vidno pozornost, vidno pomnjenje, vidno sledenje in vidno razlikovanje.

Fonološko zavedanje - Fonološko zavedanje je pri otroku razvito, ko obvlada slušno pozornost, slušno pomnjenje, slušno razločevanje glasov/ zvokov in slušno razčlenjevanje.

Abecedno znanje - Osrednja vloga abecednega znanja za pridobivanje pismenosti se nanaša na otrokovo pojmovanje črk, prepoznavanje črk in pisanje črk.

Orientacija - Orientacija je razumljena kot predhodna spretnost, ki je nujno potrebna za kakovostno izvajanje grafomotoričnih vaj in kasnejšega pisanja. Razvoj orientacije se lahko spodbuja $\mathrm{z}$ orientacijo na telesu, v prostoru in na papirju.

Grafomotorika - Grafomotorika opredeljuje otrokovo spretnost pisanja vodoravnih črt, navpičnih črt, poševnih črt, krožnih črt, valovitih črt in zank, kar služi kot izhodišče za pisanje.

Naštete kategorije se nanašajo na vzpostavitev vertikalne povezave razvijanja predopismenjevalnih spretnosti $\mathrm{v}$ vrtcu in na začetno šolanje $\mathrm{v}$ osnovni šoli.

\section{Kriteriji ugotavljanja kakovosti dokumentov}

Izbira dokumenta ni bila izvedena stihijsko, temveč je temeljila na utemeljenih kriterijih (po Scott, 1990 in Hodder, 2003, v Vogrinc, 2008: 136-140) avtentičnosti, kredibilnosti, jasne sporočilnosti, reprezentativnosti, kriteriju povezanosti in skladnosti.

\section{Rezultati}

V Kurikulumu za vrtce (1999) (v nadaljevanju kurikulum) so za vsako posamezno področje dejavnosti opredeljeni splošni cilji, iz katerih so izpelja- 
ni podrobni cilji. Dodatno so navedena načela, ki so pomembna za uresničevanje ciljev. Temu sledi opredelitev metodike, ki je razdeljena na prvo in drugo starostno obdobje, dodana pa je tudi vloga vzgojitelja. V Učnem načrtu za slovenščino (2011) (v nadaljevanju učni načrt) so opredeljeni predmeti, čemur sledijo splošni cilji, ki so vezani na vse razrede osnovne šole. Dodatno so zapisani operativni cilji z dodanimi vsebinami za vsako vzgojno-izobraževalno obdobje posebej, vezano na področje jezika oziroma področje književnosti. Načela niso posebej izpostavljena, ker se le ta navezujejo na Belo knjigo (2011). Zapisana so tudi didaktična priporočila, ki so v pomoč učiteljem.

Področje interesa $z a$ branje se $\mathrm{v}$ kurikulumu najmočneje povezuje $\mathrm{z}$ vsemi petimi strukturnimi postavkami, tj. načelom, cilji, metodiko prvega in drugega starostnega obdobja in vlogo vzgojitelja. Poudarjeno je glasno in interpretativno branje, ki krepi otrokovo zanimanje za branje. Ob poslušanju glasnega branja otroci doživljajo ugodje in veselje, pri čemer pridobiva pozitiven odnos do literature, dodatno pa se spodbuja doživljanje domišljijskega sveta. Če prvo starostno obdobje poudarja branje vzgojitelja, pa to v drugem nadgradi z vključevanjem drugih medijev. Interes branja se spodbuja s pogovorom po prebranem besedilu, pri čemer se otroke vključuje $\mathrm{k}$ odgovarjanju na vprašanja, opisovanju prebranega besedila, interpretaciji ilustracij. V drugem starostnem obdobju otroci v pogovoru o besedilu že vključujejo tudi svoje teme, kar poveča interes za branje. Vloga vzgojitelja je prepoznana v ponujanju različnih žanrov besedila, ki se nanašajo na poslušanje otroških pravljic, zgodbic, ugank, pesmic, pripovedi o dogodkih ter seznanjanje z leposlovnimi knjigami in s priročniki. Vzgojitelji lahko otrokom omogočijo igro s knjigami in ustvarjanje svoje knjige oziroma stripa. Področje interesa $z a$ branje se $\mathrm{v}$ učnem načrtu najmočneje povezuje s splošnimi cilji in didaktičnimi priporočili. Interes za branje se spodbuja ob branju in poslušanju besedil, $\mathrm{z}$ vodenim pogovorom po prebranem ali poslušanem besedilu. Dodatno učenci lahko vrednotijo zmožnost kritičnega poslušanja neumetnostnih besedil, glasno in interpretativno berejo, ustno obnavljajo besedilo, prepoznavajo pomena in vloge nebesednih sporočil, ob lastnih izražanjih primerjajo svoja doživljanja, čustva, predstave, misli, izražajo mnenje o prebranem besedilu, primerjajo in vrednotijo posamezno besedilo, opažajo razlike med besedili, se domišljijsko vživljajo $\mathrm{v}$ svet književnih besedil itn. Bralni interes temelji tudi na ponujanju zahtevnejših besedil, glasnem in interpretativnem branju, pogovoru o prebranem besedilu in predstavitvijo različnih žanrov besedil. Pomembno vlogo nosi 
postopno, sistematično in individualizirano poučevanje branja in pisanja, ki krepi interes za branje ter posledično razmišljanje, ustvarjanje, učenje in razvedrilo. Določene konkretne naloge, kot npr. iskanje naslova dani pesmi, izražanje razumevanja pesmi, zaznavanja likovne oblikovnosti besedila, razvijanje asociativnih zmožnosti itn. pomembno vplivajo na interes branja.

Področje, ki opredeljuje koncept tiska se v kurikulumu najmočneje povezuje s cilji in vlogo vzgojitelja. Pri opisu jezikovnega področja sta izpostavljena pomembnost zbliževanja otrok s knjigo kot pisnim prenosnikom ter zgodnje navajanje na rabo knjige. V širšem pomenu sodita sem vključevanje otrok v pisno kulturo in neposredno pridobivanje znanja vezanega na koncept tiska. Cilji določajo tudi otrokovo spoznavanje knjige kot vira informacij. Poudarjen je pomen spoznavanja simbolov pisnega jezika ter knjižno terminologijo, kar poteka s pomočjo igre, v katero so vključene različne oblike tiska. Otroci v drugem starostnem obdobju znanje o konceptu tiska že vnašajo v izdelavo knjige. Vzgojitelj lahko na znanje o konceptu tiska širi s pripovedovanje in branje pravljic, zgodbic, ugank, pesmic, igro s knjigami, oblikovanjem aktivnosti za ustvarjanje knjige ali stripa in uporabo tiska v vsakdanjem življenju. Področje, ki opredeljuje koncept tiska, je v učnem načrtu zastopano v splošnih ciljih, kjer je opredeljena spretnost orientacije knjige, poznavanje smeri tiska, usmerjanje pozornosti v smer pisanja, razlikovanje velikih in malih tiskanih črk. Ločevanje začetka in konca zgodbe se vrši na podlagi vrednotenja besedila ali pa s pisanjem polveznih besedil. Splošni cilj pa spodbuja tudi uporabo knjižne terminologije. Koncept tiska se močneje ne povezuje $z$ operativnimi cilji jezika in književnosti ter didaktičnimi priporočili.

Področje besedišča se v kurikulumu najmočneje povezuje s petimi strukturnimi postavkami in je temeljnega pomena za razvoj otrokovega govora. Pri tem gre za spodbujanja jezikovnih zmožnosti, tj. artikulacije, besedišča in komunikacije. Besedišče se $\mathrm{z}$ vidika ciljev krepi skozi doživljanje knjige kot ugodja in veselja, s čimer se krepi tudi bralni interes. V prvem starostnem obdobju je poudarek na igranju jezikovnih iger, ter seznanjanju z leposlovnimi knjigami in priročniki. Otrok širi besedišče tudi s pomočjo dramatizacije, izmišljanjem zgodbic, pesmic, pravljic, izštevank, rim, šaljivk, ugank, besednih iger ipd. Učenje besedišča v različnih socialnih in jezikovnih igrah, s pripovedovanjem, opisovanjem in $\mathrm{z}$ rabo jezika $\mathrm{v}$ domišljijskih igrah pa so aktivnosti, ki prehajajo iz prvega v drugo starostno obdobje. V drugem starostnem obdobju se besedišče krepi z obiskom 
gledaliških in/ali filmskih predstav in obiskom splošne knjižnice, s spodbujanjem vsakodnevne komunikacije, sodelovanjem v različnih govornih položajih ter vpeljevanju novih pogovornih tem. Dodatno vplivajo na pridobivanje besedišča družabne in didaktične igre ter poslušanje avdio in video gradiv. Otroka se usmerja v samostojno pripovedovanje, da izraža lastne misli. Vloga vzgojitelja ni eksplicitno razdeljena na količinski in kakovostni vidik razvoja besedišča. Od vzgojitelja se pričakuje, da otrokom pripoveduje in bere pravljice, zgodbe, uganke, pesmice, primerne njihovi starosti, in uprizarja lutkovne igre. Vzgojitelj naj bi v manjših skupinah izkoriščal priložnosti za poglobljen pogovor $\mathrm{z}$ otrokom in ga spodbujal $\mathrm{k}$ pripovedovanju (npr. o prebranem besedilu). Področje besedišča se v učnem načrtu najmočneje povezuje $s$ splošnimi cilji in didaktičnimi priporočili. Splošni cilji usmerjajo pedagoško delo $\mathrm{h}$ kritičnemu sprejemanju neumetnostnih in umetnostnih besedil, vrednotenju besedil in utemeljevanju svojega mnenja, dialogu o književnem besedilu, pogovarjanju in dopisovanju ter govornemu nastopanju in tvorjenju besedil ter pridobivanju književnega znanja. $\mathrm{Z}$ vidika operativnih ciljev jezika učenci sodelujejo v igri vlog, povzemanju teme in bistvenih podatkov, določanju okoliščin nastanka besedila in sporočevalčevega namena, vrednotenju zanimivosti, razumljivosti, resničnosti besedila, govornem nastopanju, pisnem tvorjenju povedi, pisanju veznih besedil (npr. narek, prepis), pisanju polveznih besedil (npr. neurejen niz slik), urjenju v ogovarjanju oseb v ustreznih okoliščinah, vrednotenju bralne in pisne zmožnosti, predlaganju izboljšav svojega branja in pisanja, uporabljanju časovnih prislovov. $Z$ vidika operativnih ciljev književnosti se učence spodbuja k izražanju in primerjanju svojih doživetij, čustev, misli, predstav ter utemeljevanju razlogov določene pomembnosti, sledenju zaporedja dogodkov, vživljanju v književno osebo, obnavljanju zgodbe, branju posameznih delov pravljic, iskanju podobnosti in razlik s književno osebo, doživljanju in razumevanju književnega prostora in časa, ločevanju realnega sveta od domišljijskega, razvijanju občutka za zvočnost jezika $\mathrm{z}$ iskanjem besedne dvojice, ki se rimata, tvorjenjem rimanih verzov, dopolnjevanju manjkajočih rim, tvorjenju sopomenskih nizov, izmišljanju novih besed daljših ali krajših, iskanju asociacij na dano besedo, razvrščanju dogodkov glede na čas ter vzrok in posledico, tvorjenju govornega besedila $\mathrm{z}$ različnimi pripovedovalci, tvorjenju pravljic, izdelovanju slikanic, primerjanju in vrednotenju besedila. Učitelj naj bi s smernicami didaktičnih priporočil zagotavljal sistematično učenje branja in pisanja $\mathrm{v}$ smiselnih, funkcionalnih 
in zanimivih okoliščinah ter usmerjal pozornost učencev $k$ pomenski in izrazni plati besedila.

Na področju vidnega zaznavanja se v kurikulumu kažejo najmočnejše povezane na treh strukturnih postavkah - ciljih, metodiki drugega starostnega obdobja in vlogi vzgojitelja. Cilji se s pomočjo knjig in drugih oblik tiska nanašajo na spoznavanje simbolov pisnega jezika s pomočjo knjige. $\mathrm{V}$ drugem starostnem obdobju otrok že uporablja različne simbole, s katerimi izraža svoje misli, dodatno pa lahko že ustvarja prve knjige in stripe. Vloga vzgojitelja je prepoznana $\mathrm{v}$ spodbujanju uporabe tiska in črk v vsakdanjem kontekstu. S področjem vidnega zaznavanja so $v$ učnem načrtu najmočnejše povezane $z$ operativnimi cilji jezika in književnosti ter didaktičnimi priporočili. Operativni cilji jezika se nanašajo na glasno branje od besed do preprostega besedila, opredeljujejo pa tudi pisanje besed, povedi in kratkih besedil. Učenci naj bi pisali vezna in polvezna besedila; besede z nekritični$\mathrm{mi}$ in s kritičnimi glasovi; predloge naj bi ločili od naslednje besede ter ločili nikalnico pred glagolom. Učenci naj bi zapisovali veliko začetnico na začetku povedi; v lastnih imenih; zemljepisnih imenih; svojilnih pridevnikih izpeljanih iz lastnih imen bitij. Pisali naj bi končna ločila in vejico pri naštevanju ter glavne in vrstilne števnike. Operativni cilji književnosti se nanašajo na likovno oblikovnost pesmi ali besedila; »branje« ilustracije in besedila; določanje zaporedja likovnih ilustracij; obnavljanje zgodbe s pomočjo sličic (lahko z dodanim zapisom); iskanje besednih dvojic pri rimah; iskanje sopomenskih nizov; daljšanje in krajšanje besed, tvorjenje novih besed; pisanje asociacij; risanje književne osebe. Učiteljeva vloga je prepoznana $\mathrm{v}$ sistematičnem vodenju pri branju in pisanju, spodbujanju povezovanja besednega sporazumevanja na slušni in vidni ravni z nebesednim sporazumevanjem in drugimi predmeti.

Področje fonološkega zavedanja se v kurikulumu najbolj odraža v posameznih ciljih, ki so povezani $\mathrm{z}$ načeli in metodiko drugega starostnega obdobja. Otrokovo fonološko zavedanje se krepi s poslušanjem in uživanjem $\mathrm{v}$ različnih glasovih, $\mathrm{z}$ besednimi igrami, rimami, šalami. Otroci naj bi se z glasovi igrali in tako doživljali zvočnost in ritem besed. Dodatno krepijo slušno pozornost s poslušanjem preprostih zgodb, ki jih $\mathrm{v}$ drugem starostnem obdobju lahko $v$ obliki simbolne igre ali igre vlog tudi uprizorijo. Vzgojitelji otroke vodijo v igro, kjer se ti igrajo z glasovi in posameznimi besedami. Področje fonološkega zavedanja se $\mathrm{v}$ učnem načrtu najbolj odraža $\mathrm{v}$ operativnih ciljih jezika in književnosti ter didaktičnih priporočilih. Fonološko zavedanje otrok v operativnih ciljih jezika krepi s pisanjem 
in branjem besed, vezanimi in polvezanimi besedili, pisanjem besed s kritičnimi in nekritičnimi glasovi, ločenim pisanjem predloga in naslednje besede ter nikalnice pred glagolom, pisanjem glasnih in vrstilnih števnikov, pisanjem velike začetnice $\mathrm{v} v$ seh njenih vlogah, pozornim poslušanjem enogovornih neumetnostnih besedil, prepoznavanjem naglasov ter intonacije pri branju, odpravljanjem napak pri branju in pisanju. Tvorjenje manjšalnic, ljubkovalnic, iskanje ženskega para moškemu in obratno ter izpeljava samostalniških in pridevniških izpeljank dodatno vpliva na fonološko zavedanje. Operativni cilji književnosti se nanašajo na govorne položaje pri poslušanju in branju, zaznavanje bralnih napak ob ponovnem branju, sledenje zaporednemu toku dogodkov, obnavljanje zgodbe, razvrščanje zgodbe v časovno zaporedje, razvijanje občutka za zvočnost jezika, iskanje rim in manjkajoče rimane besede, sopomenke. Ločijo dolge in kratke besede, tvorijo nove besede - skovanke, izpeljanke, zapisujejo asociacije na besede. Vloga učitelja se nanaša na sistematično spoznavanje in urjenje branja in pisanja s sporazumevalnimi dejavnostmi v smiselnih, funkcionalnih in zanimivih okoliščinah. Pomembno je, da učitelj postopno, sistematično in individualizirano poučuje branje in pisanje ter uvaja rabo pisnega jezika za sporazumevanje, razmišljanje, ustvarjanje, učenje in razvedrilo.

Abecedno znanje se v kurikularni zasnovi najmočneje povezuje s cilji, metodiko drugega starostnega obdobja in vlogo vzgojitelja. $\mathrm{V}$ okviru abecednega znanja otroci spoznavajo vlogo simbolnega in pisnega jezika. $\mathrm{V}$ drugem starostnem obdobju se abecedno znanje spodbuja $\mathrm{z}$ igro, ki vključuje črke v povezavi z glasovi, kar sočasno krepi tudi fonološko zavedanje. Otroci s pisnimi simboli izražajo svoje misli. Pomembno je, da vzgojitelj ustvarja pogoje, da se lahko otroci izražajo s pisnimi simboli. Vzgojitelj naj bi pisal otrokovo ime na izdelke in stvari, ki so njegove ter $\mathrm{z}$ zgledom nagovarjal otroke k uporabi pisnih simbolov. Predvsem naj bi bilo abecedno znanje prepleteno $\mathrm{z}$ uporabo tiska $\mathrm{v}$ kontekstu otrokovega vsakdana. $\mathrm{V}$ učnem načrtu vlogo abecednega znanja najmočneje povezujemo s splošnimi cilji in didaktičnimi priporočili. Prvi splošni cilj predvideva razvoj abecednega znanja za pisanje, drugi cilj pa se osredotoča na razvijanje sporazumevalnih zmožnosti ter v okviru jezikovnih zmožnosti (poimenovalnih, skladenjskih, pravorečnih in pravopisnih) vpliva na abecedno znanje. V okviru didaktičnih priporočil učitelj pri učencih sočasno razvija vse prvine abecednega znanja. Gre za priporočilo o sistematičnem razvijanju predopismenjevalnih zmožnosti in za priporočilo o postopnem, sistematičnem in 


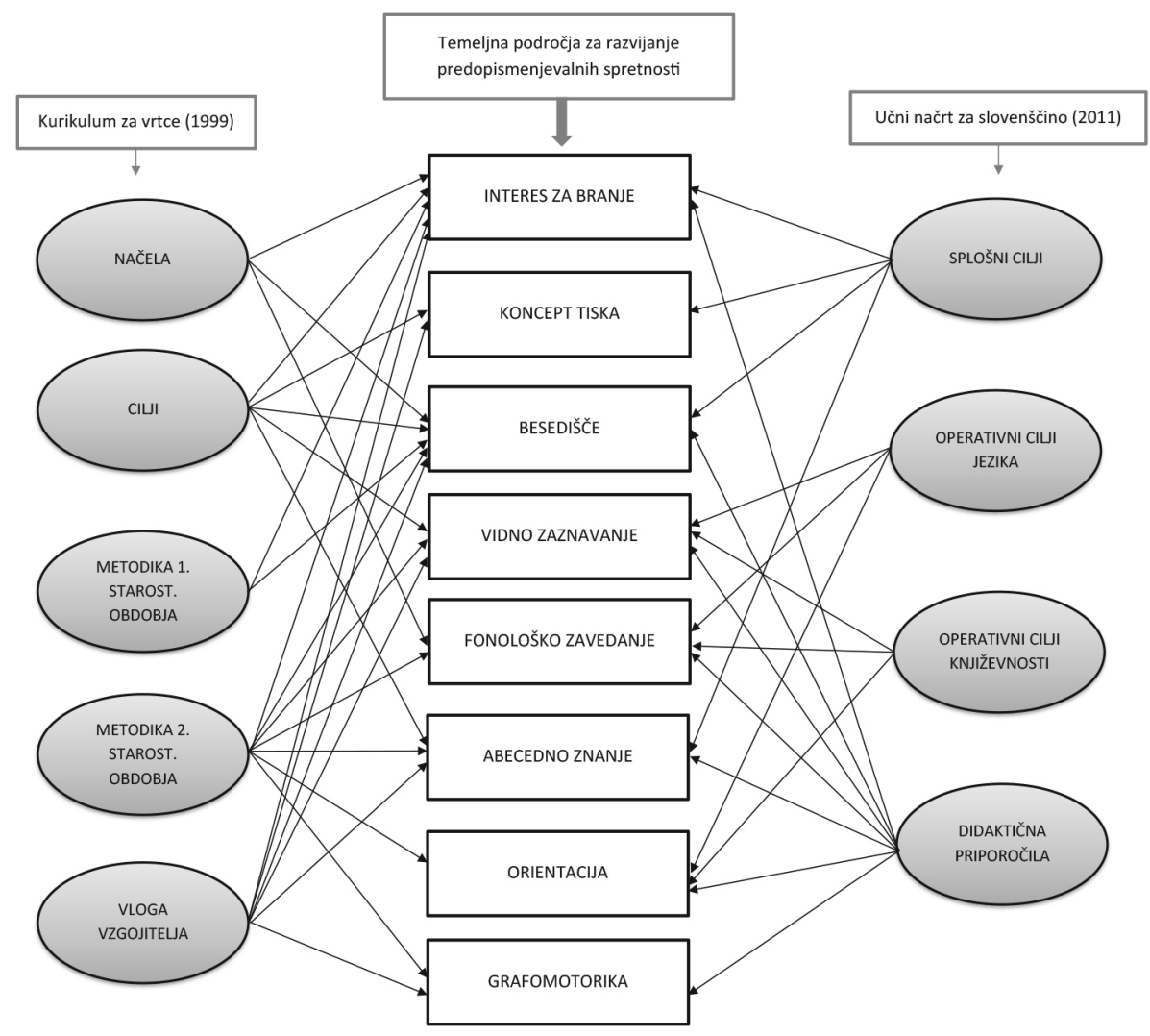

Slika 4: Prikaz povezave načel, ciljev, metodike I. starostnega obdobja in 2. starostnega obdobja ter vloge vzgojitelja glede na posamezna področja razvijanja predopismenjevalnih spretnosti, ki jih opredeljuje Kurikulum za vrtce (1999), in shematski prikaz povezav med splošnimi cilji, operativnimi cilji jezika, operativnimi cilji književnosti ter didaktičnimi priporočili glede na posamezna področja razvijanja predopismenjevalnih spretnosti, ki jih opredeljuje Učni načrt za slovenščino (20II)

individualiziranem poučevanju branja in pisanja ter rabe pisnega jezika za sporazumevanje, razmišljanje, ustvarjanje, učenje in razvedrilo.

Orientacija se v kurikulumu z vidika ciljev najmočneje veže na razvoj orientacije na telesu in $\mathrm{v}$ prostoru, ne pa tudi na orientacijo na papirju. $\mathrm{V}$ prvem starostnem obdobju jo otroci razvijajo s prstnimi igrami, akcijskimi igrami, prostimi skupinskimi oziroma individualnimi plesnimi in rajalnimi igrami. Otrokova orientacija na telesu in v prostoru se razvija prek simbolnih iger ali iger vlog, ko otroci posnemajo in igrajo osebe, živali ali predmete. Orientacija se $\mathrm{v}$ učnem načrtu najmočneje povezuje $\mathrm{z}$ operativnimi 
cilji jezika in književnosti ter didaktičnimi priporočili, kjer se v okviru zgodnjega in začetnega učenja branja in pisanja razvija učenčeva orientacija na telesu, $v$ prostoru in na papirju. Učenci se ob poslušanju enogovornih neumetnostnih besedil likovno izražajo na papirju. Ostala dva vidika orientacije nista eksplicitno zapisana, lahko pa ju učitelj izvaja tudi v okviru drugih dejavnosti. Pri operativnih ciljih jezika se orientacija navezuje na zapisovanje črk, besed in besedil, prepisa, zaporednega nizanja slikovnega gradiva, uporabo velike in male tiskane črke. Pri operativnih ciljih književnosti pa orientacijo prepoznamo v zaznavanju likovne oblikovanosti pesmi oziroma besedila, branju ilustracij in besedila, likovnem izražanju književne osebe, obnavljanju zgodbe $\mathrm{z}$ uporabo slikovnega materiala.

Grafomotorika se v kurikulumu najmočneje povezuje z drugim starostnim obdobjem in vlogo vzgojitelja. Pojma grafomotorika v kurikulumu ne zaznamo, lahko pa to prepoznamo $\mathrm{v}$ izrazu predpisalnih sposobnostih in spretnostih. Podrobneje se pojem nanaša na ustvarjanje lastne knjige, uporabo različnih simbolov, ki jih otroci izražajo in jih ponovno lahko prebirajo. Grafomotorika se v učnem načrtu najmočneje povezuje z didaktičnimi priporočili. Pri tej dejavnosti je opis sorazmerno splošen. Nanaša se na pravilno držo pisala. Vloga učitelja je prepoznana v postopnem, sistematičnem in individualiziranem poučevanju pisanja. Pisanje različnih grafomotoričnih oblik, ki vodijo učenca do pisanja črk se lahko dosega s pomočjo operativnega cilja jezika, ki izpostavlja sistematično razvijanje predopismenjevalnih zmožnosti. V kontekstu grafomotorike je večja pozornost namenjena oblikovanju črk, kot nadgradnja grafomotorike.

\section{Interpretacija}

Razlike med kurikulumom in učnim načrtom zaznamo v strukturi dokumentov, saj kurikulum opredeljuje načela, medtem ko teh $\mathrm{v}$ učnem načrtu ni mogoče zaslediti, se pa pri tem lahko opremo na načela, ki so zapisana v Beli knjigi (2011: 112-115). Vidnejše razlike se nanašajo na cilje, saj kurikulum splošno izpostavi cilj, ki pokriva več kot polovico predopismenjevalnih področij, medtem ko so pri učnem načrtu cilji opredeljeni kot splošni cilji, nato pa sledi podrobnejša opredelitev, ki se nanaša na operativne cilje jezika in operativne cilje književnosti. Tako kot kurikulum tudi učni načrt $\mathrm{v}$ vseh svojih ciljih zajame večino predopismenjevalnih spretnosti.

Kurikulum (1999) v prvem starostnem obdobju opredeli dve močnejši povezavi s predopismenjevalnimi spretnostmi, tj. interesom za branje in razvojem otrokovega besedišča. V drugem starostnem obdobju je kot 
močna povezava opredeljena večina predopismenjevalnih spretnosti. Kurikulum večjo težo za razvijanje predopismenjevalnih spretnosti namenja starejšim otrokom, mlajšim pa namenja večjo vlogo, ki je vezana na poslušanje in govorjenje. Takšna struktura se navezuje na sporazumevalni zmožnosti poslušanja in govorjenja, kar se razume kot primarni spretnosti. Dodatno se že v rani otroški dobi oblikujejo bralne navade, kar se povezuje s pozitivnim bralnim doživljanjem (Aerila in Merisuo-Storm, 2017; Suggate et al., 2013; Tompkins, 2011). V drugem starostnem obdobju so še vedno najmočnejše povezave na področju interesa za branje in razvoja otrokovega besedišča. Manj povezav, še vedno pa dovolj ustrezno, pa se kaže pri fonološkem zavedanju, vidnem zaznavanju in orientaciji. Kurikulum upošteva otrokov razvoj in $\mathrm{v}$ drugem starostnem obdobju dodaja področja, ki so pomembna za razvoj predopismenjevalnih spretnosti. Analiza ne kaže močnejših povezav z grafomotoriko in abecednim znanjem otrok, čeprav te sodijo v kategorijo temeljnih znanj predopismenjevalnih spretnosti. Tuji kurikulumi se nanašajo na razvijanje grafomotorike in poučevanje črk, vendar raziskave kažejo, da je pedagoška osredotočenost na dejavnost poučevanja črk premajhna (Piasta in Wagner, 2010). Kurikulum (1999) poudarja avtonomijo vzgojitelja, kar v pedagoški praksi omogoča zavzeto razvijanje grafomotoričnih spretnosti in abecednega znanja.

Učni načrt je razdeljen na tri vzgojno-izobraževalna obdobja. Predopismenjevalne spretnosti smo analizirali v prvem vzgojno-izobraževalnem obdobju, saj se te vsebinsko smiselno navezujejo na začetno izobraževanje $\mathrm{v}$ osnovni šoli. Največ povezav na področju predopismenjevalnih spretnosti najdemo tako pri vlogi vzgojitelja v kurikulumu kot pri didaktičnih priporočilih za učitelje. Okvir učnega načrta zajema različna področja, ki so za razvijanje predopismenjevalnih spretnosti pomembna $\mathrm{v}$ začetnem šolskem obdobju. Ugotovitve raziskave kažejo, da je pozornost v začetnem šolskem obdobju $\mathrm{z}$ vidika splošnih ciljev najbolj osredotočena na interes branja, koncept tiska, besedišče in abecedno znanje. $Z$ vidika operativnih ciljev pa je najmočnejše povezave mogoče izpostaviti na področju vidnega zaznavanja, fonološkega zavedanja in orientacije. Največ povezav zasledimo pri didaktičnih priporočilih za učitelje, kjer se kažejo najmočnejše povezave skoraj na vseh področjih razen na področju koncepta tiska.

\section{Zaključek}

Namen raziskave je bil preučiti povezovanje posameznih področij, ki so temeljnega pomena za razvijanje predopsimenjevalnih spretnosti, s struk- 
turnimi zasnovami Kurikuluma za vrtce (1999) in Učnega načrta za slovenščino (2011). Ugotovitve raziskave kažejo, da se strukturni elementi obeh nacionalnih dokumentov, to so: cilji, načela, metodike ter priporočila in didaktična izhodišča za strokovne delavce, različno povezujejo s posameznimi področji za razvijanje predopismenjevalnih spretnosti. Dodatne ugotovitve raziskave kažejo na neenako povezanost predopismenjevalnih spretnosti v celotnem predšolskem obdobju. To vrzel lahko vzgojitelji zapolnijo in udejanijo $\mathrm{z}$ načelom strokovne avtonomije (Bela knjiga, 2011: 13) in načelom kakovosti vzgojno-izobraževalnega procesa (Bela knjiga, 2011: 15). Zaradi razlik v povezovanju predopismenjevalnih spretnosti s strukturnimi zasnovami, morajo strokovni delavci dobro poznati relevantno strokovno literaturo, ki se nanaša na razvijanje predopismenjevalnih spretnosti otrok v vrtcu in $\mathrm{v}$ začetnem šolskem obdobju, da lahko začrtane cilje in načela prenesejo $\mathrm{v}$ operativne načrte in aktivnosti prilagajajo razvojnim potrebam otrok.

Kot ugotavlja Skubic (2012), tudi ta raziskava kaže na smiselnost jasnejše opredelitve dejavnosti za razvijanje predopismenjevalnih spretnosti. Zaradi prehajanja otrok iz vrtca $\mathrm{v}$ osnovno šolo, kjer se kaže šibko sodelovanje med deležniki in neenaka jezikovna podpora otrokom (Požar Matijašič et al., 2017), bi bil smiseln razmislek o poenotenju programskih struktur, ki bi dajale strokovnim delavcem enotna izhodišče $\mathrm{v}$ obeh nacionalnih dokumentih na področju razvijanja predopismenjevalnih spretnosti. Dodatno bi lahko podali predloge za intenziteto izvajanja predopismenjevalnih spretnosti ter določili razvojne ravni, ki bi vzgojiteljem v vrtcu služile kot smernice za pedagoško delo. Tudi Nacionalna strategija za razvoj bralne pismenosti (2019: 5-7) izpostavi celostni in sistemski pristop razvijanja porajajoče se pismenosti, ki se nadaljuje s procesom začetne pismenosti. S tem nakaže smiselnost vertikalnega povezovanja procesa pismenosti med obema izobraževalnima programoma. Kljub izsledkom raziskave se je potrebno zavedati, da je še tako kakovostno zasnovan kurikularni program zgolj smernica za uresničevanje pedagoških dejavnosti, od strokovnih delavcev pa je odvisna implementacija posameznih področij za razvijanje predopismenjevalnih spretnosti.

\section{Literatura}

Aerila, Juli-Anna, and Merisuo-Storm Tuula. »Emergent Readers and the Joy of Reading: A Finnish Perspective." Creative Education 8, no. 15 (2017): 2485-2500. 
Baloh, Barbara. »Od črte, do črke: priročnik k delovnemu zvezku za razvoj grafomotoričnih spretnosti in sposobnosti.« Trst: ZTT-EST, 2019.

»Bela knjiga o vzgoji in izobraževanju v Republiki Sloveniji.« Edited by Krek, Janez, and Mira, Metljak. El. Knjiga. Ljubljana: Zavod RS za šolstvo, 2011. http://pefprints.pef.uni-lj.si/1195/1/bela_knjiga_2011.pdf.

Bole, Velimir, Žiga, Jere, and Peter, Rebec. »Učinkovitost sistema izobraževanja v Sloveniji.« Ljubljana: Sindikat vzgoje, izobraževanja, znanosti in kulture Slovenije, 2016.

Cencič, Majda, and Barbara, Horvat. »Prehod iz vrtca v šolo na primeru izvedbe vzgojno-izobraževalnih dejavnosti zunaj prostora ustanove.« Revija ta elementarno izobraževanje 14, no. 1 (2021): 47-71.

Cunningham, Denise, D. »Relating preschool quality to children's literacy development.« Early Childhood Education Journal 37, no. 6 (2010): 501-507.

Dickinson, David P., Kimberly T., Nesbitt, Molly F., Collins, Elizabeth B., Hadly, Katherine, Newman, Bretta L., Rivera, Hande, Ilgez, Angeliki, Nicolopoulou, Roberta, Michnick Golinkoff, and Kathy, Hirsh-Pasek. »Teaching for breadth and depth of vocabulary knowledge: Learning from explicit and implicit instruction and the storybook texts." Early Childhood Research Quarterly 47, (2019): 341-356.

Hachey, Alyse C. »The Early Childhood Mathematics Education Revolution.« Early Education and Development 24, no. 3 (2013): 419-430.

Hair, Elizabeth, Tamara, Halle, Elizabeth, Terry-Humen, Bridget, Lavelle, and Julia, Calkins.“ Children's school readiness in the ECLS-K: Predictions to academic, health, and social outcomes in first grade." Early Childhood Research Quarterly 21, no. 4 (2006): 431-454.

Heckman, James, J. »The Case for Investing in Disadvantaged Young Children." European Expert Network on Economics of Education (EENEE), Policy Brief 1, 2012.

Jalongo, Mary R. »Information Literacy in Early Childhood: What, Why, How, and Where to Next? " V Young Children and Families in the Information Age: Applications of Technology in Early Childhood, edited by Heider, Kelly L., and Mary R, Jalongo. New York: Springer Science and Business Media, 2015.

Kogut, Bruce, and Charles, Ragin. „Exploring complexity when diversity is limited: institutional complementarity in theories of rule of law and national systems revisited." European Management Review 3, no. 1 (2006): 4459. 
Kordeš, Urban, and Maja, Smrdu. »Osnove kvalitativnega raziskovanja.« El. knjiga. Koper: Založba Univerze na Primorskem, 2015. http://www.hippocampus.si/ISBN/978-961-6963-98-5.pdf.

Kroflič, Robi. »Temeljne predpostavke, načela in cilji kurikula za vrtce.« In Otrok v vrtcu: priročnik $h$ kurikulu za vrtce, edited by Ljubica, Marjanovič Umek, 7-25. Maribor: Obzorja, 2001.

»Kurikulum za vrtce: predšolska vzgoja v vrtcih.« Strokovni svet Republike Slovenije za splošno izobraževanje. Ljubljana: Ministrstvo za šolstvo in šport in Zavod Republike Slovenije za šolstvo, 1999.

Lane, Cristianne, Mary, J. surges-Prokop, Evelyn, Johnson, Blanche, Podhajski, and Jane, Nathan. "Promoting early literacy through the professional development of preschool teachers." An International Research Journal 34, no. 1 (2014): 67-8o.

Lucariello, Joan, Sandra, Graham, Bonnie, Nastasi, Carol, Dwyer, Russ, Skiba, Jonathan, Plucker, Nary, Pitonika, Nary, Brabeck, Darlene, DeMarie, and Steven, Pritzker. »Top 20 Principles from Psychology for PreK-12 Teaching and Learning." Coalition for Psychology in Schools and Education. Washington, D. C.: American Psychological Association, 2015. http://www.apa.org/ed/schools/cpse/top-twenty-principles.pdf

Marjanovič Umek, Ljubica, Urška, Fekonja, and Kaja, Hacin. »Dodatni program za spodbujanje zgodnje pismenosti v vrtcu: kratkoročni in dolgoročni učinki.« Sodobna pedagogika 3, (2019): 10-23.

Mata, Lourdes. »Motivation for Reading and Writing in Kindergarten Children."Reading Psychology 32, no. 3 (2011): 272-299.

»Nacionalna strategija za razvoj bralne pismenosti za obdobje 2019-2030.« Ljubljana: Ministrstvo za izobraževanje, znanost in šport, 2019.

»Odredba o postopnem uvajanju programa 9-letne osnovne šole.« Uradni list RS, št. 22/98, 77/oo in 62/o1. http://pisrs.si/Pis.web/pregledPredpisa?id=ODRE382

Önder, Alev, Asude, Balaban Dağal, Gülşen, İlçi Küsmüş, Hamdi, Özdemir, and Zeynep, Kaya Değer. "An investigation of visual perception levels of pre-school children in terms of different variables."International Online Journal of Education and Teaching 6, no. 1 (2019): 190-203.

Pečjak, Sonja, and Nataša, Potočnik. »Razvoj komunikacijskih zmožnosti v vrtcu in začetno opismenjevanje. "In Bralna pismenost v Sloveniji in Evropi, Zbornik prispevkov konference, edited by Fani, Nolimal, 61-8o. Ljubljana: Zavod RS za šolstvo, Ministrstvo za šolstvo in šport, Eurydice Slovenija, CMEPIUS, Pedagoški inštitut, 2011. 
Pečjak, Sonja. »Psihološki vidiki bralne pismenosti: od teorije k praksi.« Ljubljana: Znanstvena založba Filozofske fakultete, 2012.

Piasta, Shayne. B., and Richard K., Wagner. »Learning letter names and sounds: Effect of instruction, letter type, and phonological processing skill.« Journal of Experimental Child Psychology 105, no. 4 (2010): 324-344.

Požar Matijašič, Nada, Mojca, Štraus, Sonja, Rutar, Nives, Zore, and Janja, Cotič Pajntar. »Kako prehajajo otroci iz vrtca v osnovno šolo pri nas v primerjavi z vrstniki v drugih državah?« XXVI. strokovno srečanje ravnateljic in ravnateljev vrtcev. Portorož: Šola za ravnatelje, 6. in 7. november 2017. http://solazaravnatelje.si/wp-content/uploads/2017/11/Prehod-iz-vrtca-v-solo.pdf

Richman, Elizabeth R., and Leslie, Rescorla. "Academic Orientation and Warmth in Mothers and Fathers of Preschoolers: Effects on Academic Skills and Self-Perceptions of Competence." Early Education and Development 6, no. 3 (2015): 197-213.

Ropič, Marija, Mateja, Urbančič Jelovšek, and Jana, Frančeškin. „Danes rišem, jutri pišem." Priročnik za učitelje in vzgojitelje v 1. razredu devetletne osnovne šole. Ljubljana: Rokus, 2003.

Ropič, Marija. »Zmožnost zaznavanja začetnih in končnih glasov v nezložnih in večzložnih besedah." Didactica Slovenica 31, no. 1 (2016): 44-54.

Sagadin, Janez. »Pregledno o kvalitativnem empiričnem pedagoškem izobraževanju.« Sodobna pedagogika 118, no. 2 (2007): 10-25.

Saksida, Igor. »Kaj je primerna knjiga? - Le kakšno vprašanje je to!« Otrok in knjiga 76, (2009): 25-33.

Saksida, Igor. »Bralni dogodek v vrtcu."In V objemu besed: razvijanje družinske pismenosti, edited by Haramija, Dragica, 47-54. Maribor: Univerzitetna založba Univerze, Pedagoška fakulteta Maribor, 2017.

Skubic, Darija. »Stališča vzgojiteljev do zgodnje pismenosti v Sloveniji.« Revija za elementarno izobraževanje 5, no. 2/3 (2012): 153-166.

Skubic, Darija. »Otrokovo poznavanje koncepta tiska (knjige) kot pomemben del zgodnje pismenosti." Jezik in slovstvo 58, no. 3 (2013): 45-58.

Soydan, Sema. "Analyzing Efficiency of Two Different Methods involving Acquisition of Operational Skills by Preschool Children." Eurasia Journal of Mathematics, Science and Technology Education 11, no. 1 (2015): 129-138.

Suggate, Sebastian. P., Elizabeth A. Schaughency, and Elaine Reese. »Children Learning to Read Later Catch up to Children Reading Earlier." Early Childhood Research Quarterly 28, no. 1 (2013): 33-48. 
Teale, William H., Colleen E., Whittingham, and Emily, Brown Hoffman. »Early literacy research, 2006-2015: A decade of measured progress. «Journal of Early Childhood Literacy 14, no. 4: (2018): 459-481.

Tompkins, Gail E. »Literacy in the Early Grades: A Successful Start for PreK-4 Readers and Writers."Boston: Pearson, 2011.

Turnšek, Nada, and Marcela, Zorec Batistič. »PREDŠOLSKA vzgoja in varstvo v Evropi: odpravljanje socialne in kulturne neenakosti.« Edited by Plevnik, Tatjana. Ljubljana: Ministrstvo za šolstvo in šport. Brussels: EACEA $\mathrm{P}_{9}$ in Eurydice, 2009.

»Učni načrt za slovenščino. Program osnovna šola - slovenščina (posodobljena izdaja).« Ljubljana: Ministrstvo za izobraževanje, znanost in šport, Zavod RS za šolstvo, 2011.

Vallberg-Roth, Ann-Christine. »Nordic Comperative Analysis of Guidelines for Quality and Content in Early Childhood Education." Tidsskrift for nordisk barnehageforskning, 8, 2014.

Vogrinc, Janez. »Kvalitativno raziskovanje na pedagoškem področju.« Ljubljana: Pedagoška fakulteta, Univerza v Ljubljani, 2008.

»Vzgojni program priprave otrok na osnovno šolo.« Ljubljana: Zavod SR Slovenije za šolstvo, 1981.

»Vzgojni program za vzgojo in varstvo predšolskih otrok.« Ljubljana: Zavod SR Slovenije za šolstvo, 1979.

Wawire, Brenda A., and Young-Suk G., Kim. »Cross-language transfer of phonological awareness and letter knowledge: causal evidence and nature of transfer.« Online. Scientific Studies of Reading, 2018. https://www.tandfonline.com/doi/full/10.108o/10888438.2018.1474882 